DOI: https://doi.org/10.31933/dijdbm.v2i6

Received: 4 September 2021, Revised: 25 September 2021, Publish: 15 October 2021

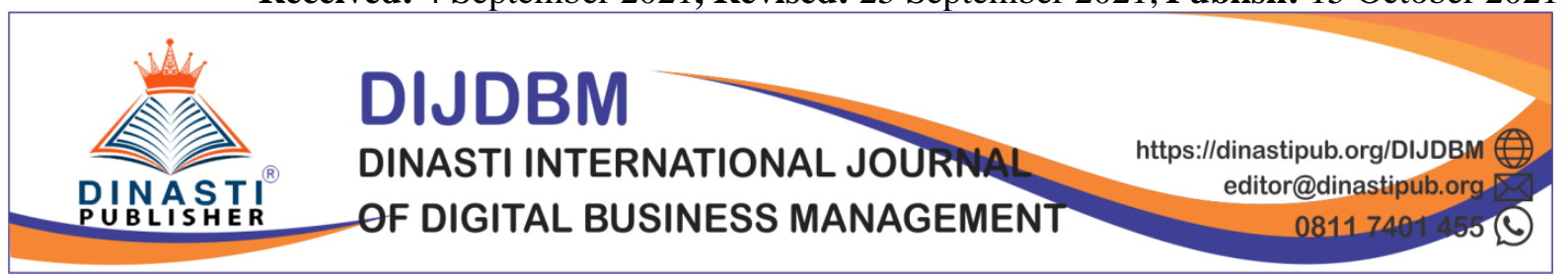

\title{
E-COMMERCE: THE IMPORTANCE ROLE OF CUSTOMER PERCEIVED VALUE IN INCREASING ONLINE REPURCHASE INTENTION
}

\author{
Johan Hendri Prasetyo ${ }^{1}$, Bobby Suryo Prakoso ${ }^{2}$, Gani Wiharso ${ }^{3}$, Luky Fabrianto ${ }^{4}$ \\ 1) Universitas Nusa Mandiri, Jakarta, Indonesia, johan.jnp@nusamandiri.ac.id \\ 2) Universitas Nusa Mandiri, Jakarta, Indonesia \\ 3) Universitas Nusa Mandiri, Jakarta, Indonesia \\ 4) Universitas Nusa Mandiri, Jakarta, Indonesia
}

Corresponding Author: Johan Hendri Prasetyo

\begin{abstract}
In the midst of digital business growth rapidly and Covid-19 pandemic that has lasted for several years, people tends to carry out all their activities from home, including fulfilling their needs through various e-commerce services. This research model intends to investigate the important role from customer perceived value in increasing online repurchase intention on various e-commerce sites in Indonesia, such as Shopee, Tokopedia, Bukalapak, Lazada and Blibli. This research method designed by quantitative causality with a total sample of 310 people through snowball sampling. The analytical method used AMOS-SEM to verified the role of customer value perceptions. This results shows that customer perceived value indirectly act as an crucial part in increasing the influence from e-service quality, ease of use, store image and online promotion on online repurchase intention.
\end{abstract}

Keywords: Customer perceived value, online repurchase intention, e-commerce, digital business.

\section{INTRODUCTION}

The growth of the Industrial Revolution these days has entered a new phase, along with the growth of digitalization in all industrial sectors, ranging from banking, education, or trade. An information report from wearesocial.com marked that in April 2021 internet usage in Indonesia arose to $88.1 \%$ from the total population (Katadata, 2021). This is due to the Covid-19 situation, which requires people to performed all their activities from home, including meeting their needs through various e-commerce services. This proven by information from Sirco (2020) which shows that an increase in the number of e-commerce tourists, such as Shopee (93.4 million), Tokopedia (86.1 million), Bukalapak (35.2 million), Lazada (22 million) and Blibli. (18.3 million) in 2020 . 
Furthermore, this digital-based trading business at the end of 2020 has increased by $33.2 \%$, equivalent to Rp. 337 trillion (Indonesia.go.id). Pointing at Jetcommerce (2021), e-commerce users will expand by $15 \%$ in the end of 2021 with an increase in revenue of US\$38 million. This certainly become a great opportunity for e-commerce industry to be able to take over the industry. With those various opportunities to get more advanced, various e-commerce companies need to continue to give a lots attention to their customers so that they will maintain to make purchases on their e-commerce sites.

Online repurchase intention is an consumer's willingness to make repeat visits in the future (Kotler \& Keller, 2018)also could be reffers to significant aspect that need to be observed by ecommerce for their survival in this industry. There are several aspects which affect online repurchase intention, such as customer perceived value (Putri, 2016), e-service quality (Rita et al., 2019), ease of use (Wilson et al., 2021), online promotion and store image (Nurhayati \& Murti, 2012). Given the phenomena and various aspects that have impact to online repurchase intention, the author wishes to help the e-commerce industry in order to continue to retain its customers through the important role of customer value as an intermediary in increasing online repurchase intention in the current digital business era.

\section{THEORETICAL REVIEW}

E-commerce can be interpreted as buying, selling and marketing goods or services through electronic systems. E-commerce is an specific part of digital business which have functions to increase sales, business efficiency, create business through new services, and expand public relations in business (Kwilinski et al., 2019; Išoraitė \& Miniotienè, 2018). Due to the importance of these activities in e-commerce, those e-commerce companies are required to evaluate the loyalty of their customers. One way to measure the customer loyalty is to make repeat purchases at a later date.

Repurchase will be realized, if customers felt those products or other services offered by ecommerce meet their expectations. To realize repeat purchases, e-commerce needs to increase customer interest to continue using their e-commerce platform. Repurchase intention is the customers willingness to buy products or services both online and offline based on the benefits they have felt (Pham \& Nguyen, 2019). Online repurchase intention will increase if it is match to customer perceptions towards products, likewise to online facilities offered by e-commerce

Customer perceived value is the evaluation felt by customers of all the benefits and costs offered by the seller/store (Kotler \& Keller, 2018). Customer perceived value should be a seller's priority to increase the profits, because customer perceived value were includes functional value in providing useful products, social and emotional value felt by purchaser, epistemic value that will arouse curiosity, and price value for the product (Ding \& Tseng 2015). These values are very crucial for e-commerce entrepreneurs to remind, cause of online customers have a tendency to focus on e-service quality, ease of use, store image, and online promotion.

E-Service Quality is an online service offered by sellers based on the reciprocal flow of information between customers and service providers so that customers can return to visit the application at a later date (Shafiee \& Bazargan, 2018). The use of technology in this business applications did not only changed the way of it services, but also changed the service delivery process, so that online entrepreneurs are required to innovate in providing the best services in order to compete with competitors.

In addition to e-service quality, the ease of use of the application were also greatly affect to the increase in customer perceived value and interest. Ease of use is an person's level of confidence in using the system without any excessive effort (Davis, 1989). Ease of use will be one 
of the main factors which felt by customers and lead to someone's interest in the system (Saidani et al., 2018), Thus it will make customers repeat theirs purchases.

Another factor which affects the customer perceived value and repurchase interest in ecommerce is store image. Store image is an charateristic from store that describes the customer's feelings towards the store in terms of value, quality, and price (Surjaatmadja \& Purnawan, 2018). The established of store image is very important because it involves consumer behavior to repurchase. With the positive image shown by the customer at the store, it will indirectly its own convenience for the customer to the store, so that he will become a regular customer and will even recommend it to others.

The important role from store image in increasing perceptions and purchase interest will not run well without an attractive promotion. Promotion is an activity in communicating product advantages (Kotler et al., 2005), through various kinds of offers such as discounts, cashback, gifts and other services that are basically useful for persuading customers to purchase the products offered. Online promotion is very useful for sales now that almost entirely switched to digital media. By doing online promotion, it will provide a strategic design for e-commerce companies to find out and expand their market share.

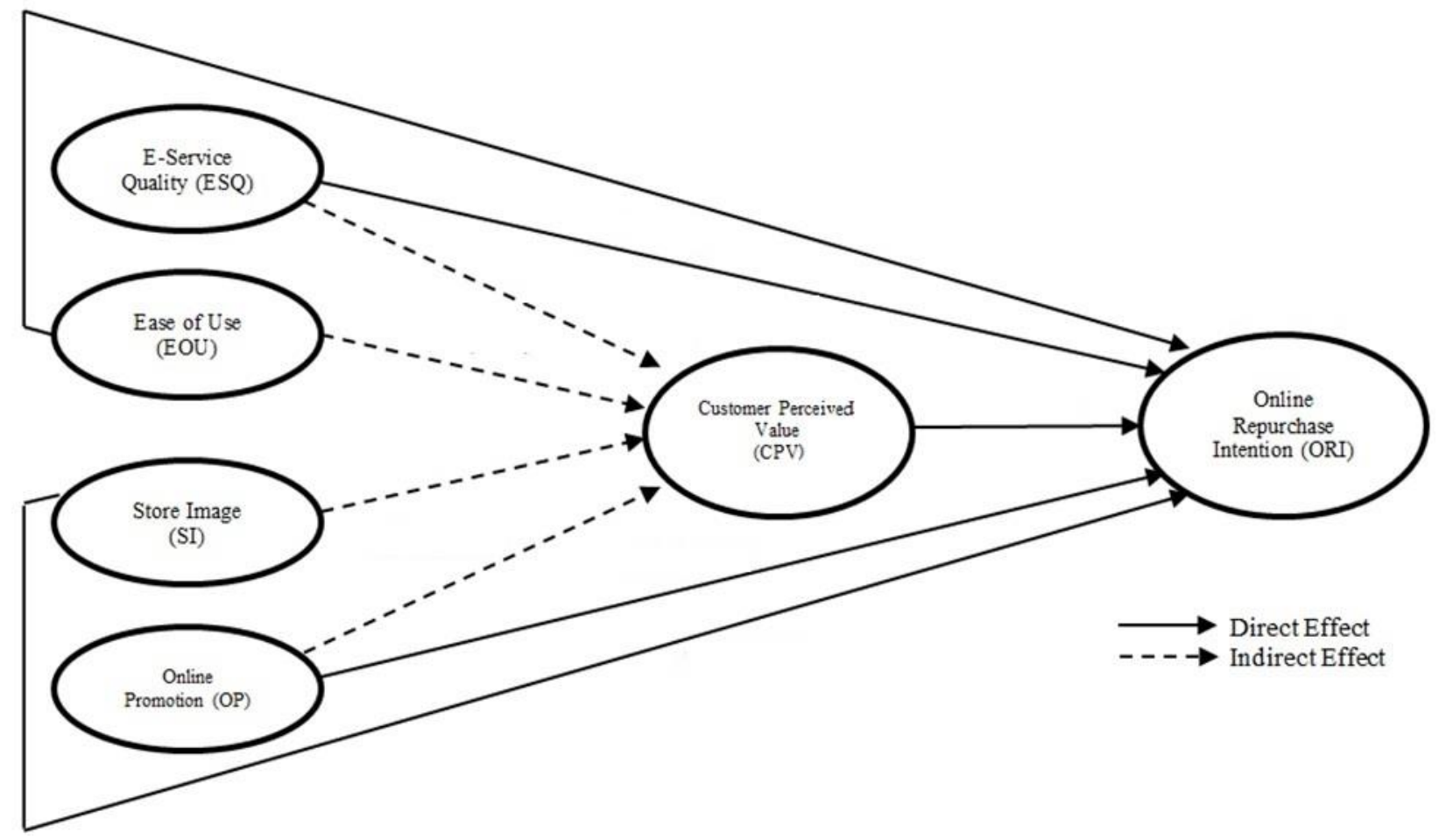

Figure 1. Conceptual Framework

\section{RESEARCH METHOD}

This research method was designed by quantitative causality with aim to investigate the important role of customer perceived value in mediating the effect of e-service quality, ease of use, store image, and online promotion to increase online repurchase intention in e-commerce. The research sample is 310 respondents who are e-commerce users of Shopee, Tokopedia, Bukalapak, Lazada and Blibli. Samples were taken through snowball sampling technique. Data distribution procedure used a Likert scale questionnaire. The analytical method used AMOS-SEM to verify the role of customer value perceptions. 


\section{RESULTS AND DISCUSSION}

From the CFA test, it was found that all 62 research indicators had a C.R. above 2.58 or what is required (Ghozali, 2017), so it is said to be valid. Then the reliability test showed all research variables had a value of $\mathrm{CR}=0.865$ to $0.978(>0.7)$ and $\mathrm{VE}=0.617$ to $0.765(>0.5)$ or as required (Ghozali, 2017), so it is said to be reliable.

Table 1. Reliability Value

\begin{tabular}{ccc}
\hline \multirow{2}{*}{ Variable } & \multicolumn{2}{c}{ Reliability } \\
\cline { 2 - 3 } & $\mathrm{CR} \geq$ & $\mathrm{VE} \geq$ \\
E-Service Quality & 0.70 & 0.50 \\
Ease of Use & 0.975 & 0.737 \\
Store Image & 0.974 & 0.765 \\
Online Promotion & 0.960 & 0.755 \\
Customer Value Perception & 0.953 & 0.669 \\
Online Repurchase & 0.865 & 0.617 \\
Intention & \\
\hline
\end{tabular}

From the structural model test, it seens that all research indicators had a critical ratio value below \pm 2.58 and p1 and p2 values $<0.001$ or required (Ghozali, 2017), so it can be concluded that the data was normally distributed.

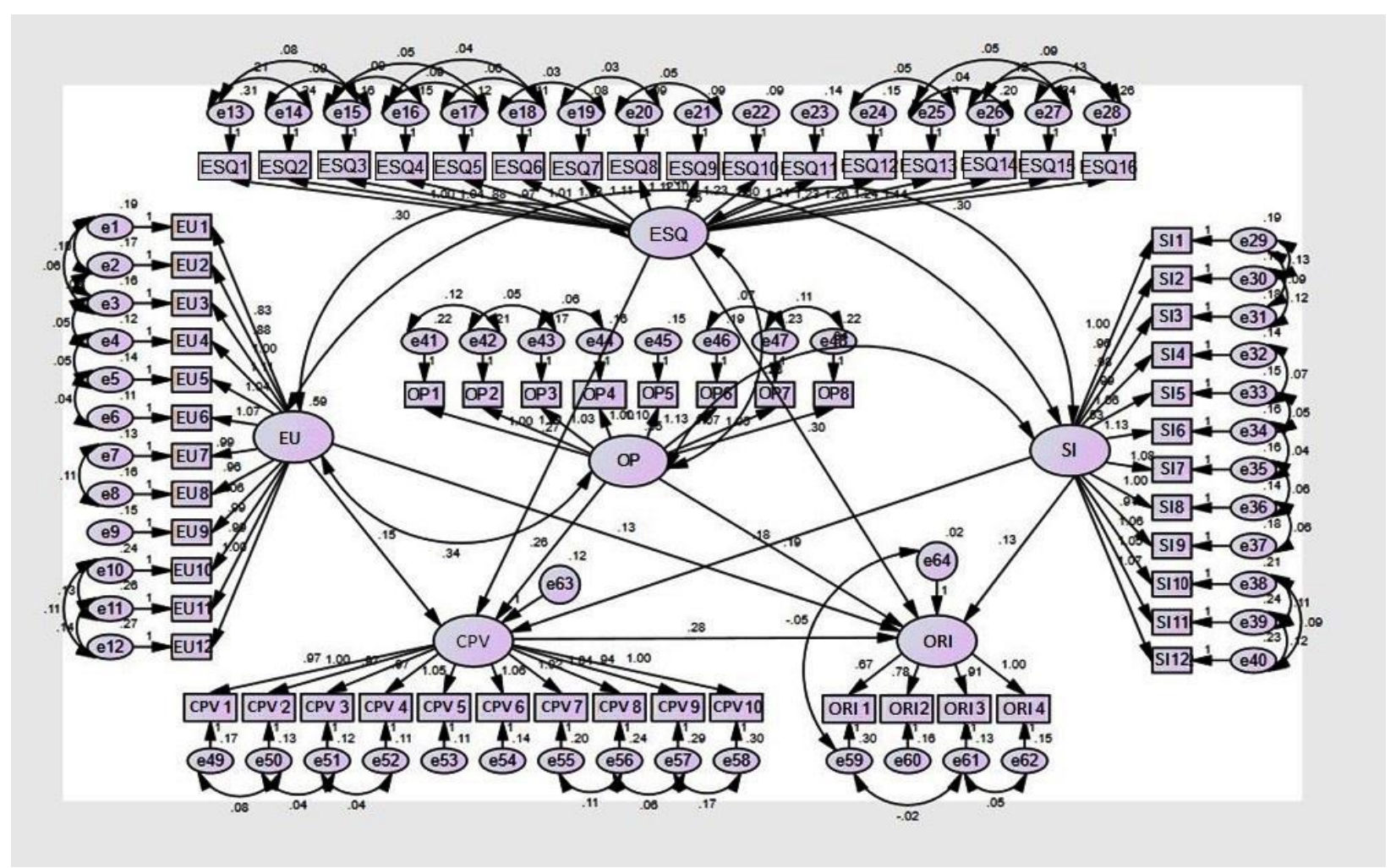

Figure 2. Structural Model

The significance test in detail can be view like in the table and figure below: 
Table 2. Significance Test

\begin{tabular}{cccc}
\hline Path & Estimate & P-Value & Result \\
\hline ESQ --> CPV --> ORI & 0.076 & $* * *$ & Hypothesis Supported \\
EOU --> CPV --> ORI & 0.043 & $* * *$ & Hypothesis Supported \\
SI --> CPV --> ORI & 0.051 & $* * *$ & Hypothesis Supported \\
OP --> CPV --> ORI & 0.073 & $* * *$ & Hypothesis Supported \\
\hline
\end{tabular}

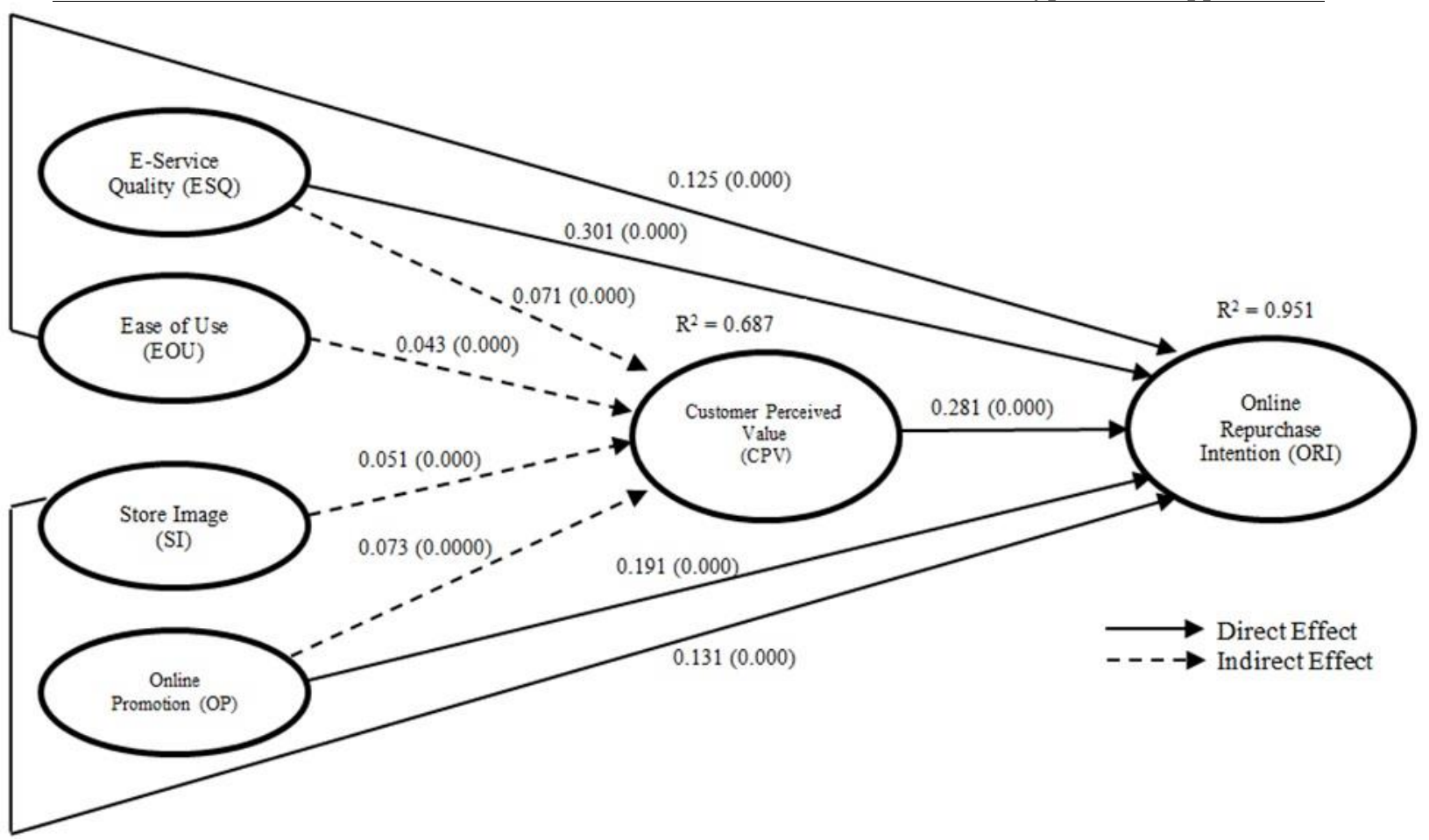

Figure 3. Empirical Model

On the significance test, it was found that e-service quality was directly affect to increase the online repurchase intention. This outcomes is in line with research by (Rita et al., 2019). This finding were illustrates about the importance of retaining consumers through online services so that customers will make repeat purchases. Therefore, e-commerce companies need to manage their existing human resources in the company through communication training and service excellence.

Store image can directly increase the online repurchase intention. This finding were in line with research by (Nurhayati \& Murti, 2012). This finding were illustrates that e-commerce needs to be more attentive and provide special training for merchants or stores that partnered with them, especially for those who have low ratings. By building the store image, it will effectively increase the value of the store in the eyes of consumers, Thereby it will indirectly build consumer behavior to make repeat orders.

Customer value perception will directly increase to online repurchase intention. This result were in line with research (Putri, 2016). This result were illustrates that the interest in using applications is periodically influenced by social incentives, such as user satisfaction, close relations with others and hedonic motivation to use applications which are all part of customer value perceptions.

Therefore, e-commerce companies need to consider and measure the value felt by customers through regular customer surveys in more real way, so that companies will know more about which details need to be remember to increase online repurchase intention in their e-commerce. 
Customer value perception plays an important role in mediating the affect of this research exogenous variable in increasing online repurchase intention. This outcomes were line with research (Putri, 2016). This finding illustrates that online repurchase intention in e-commerce will occur if a person's feelings have achieved satisfaction with the value of an application both in terms of emotional, benefits, and social related to the ease of supporting their daily activities.

Online promotion can directly increase online repurchase intention. This finding is in line with research (Nurhayati \& Murti, 2012). This finding illustrates that if online promotions are effective, it will increase repurchase intention. With online promotion, both stores and ecommerce can better communicate the products/services they sell more specifically, both in terms of advantages and benefits that will be obtained by customers, so that customers will be more interested in visiting stores through applications provided by e-commerce. .

Ease of use can directly increase online repurchase intention. This finding is in line with research (Wilson et al., 2021). This finding illustrates that someone's interest in making regular use of e-commerce applications is strongly influenced by the ease of application when used, so that customers can operate applications anywhere and anytime without wasting much time.

\section{CONCLUSION AND SUGGESTION Conclusion}

The conclusions that can be drawn from this research are:

1) E-service quality, ease of use, store image, online promotion, and customer value perception can directly increase the online repurchase intention in e-commerce at Indonesia.

2) Customer value perception indirectly plays an important role in increasing the influence of eservice quality, ease of use, store image, and online promotion on online repurchase intention.

\section{Suggestion}

Suggestions that authors can convey in this research are:

1) E-commerce companies need to optimize their services according to customer expectations and served good service quality, provide information on informative social media and other services. This can be done through periodic and ongoing surveys related to e-commerce services as well as providing a contact center with a fast response (no more than 1 x 24 hours), so that the handling of customer complaints can be resolved immediately.

2) E-commerce companies will optimize their application performance without buffering. This can be improved by minimizing the existing menu/content in the application, so that the application will be more light to use on any device, especially on devices with low storage power.

3) E-commerce companies need to optimize the role of partnered shops/merchants. This can be done by holding service excellent training at stores which have low rating ratings, as well as making breakthroughs through collaboration with the entertainment industry, so that in addition to customers being able to shop at e-commerce, customers can also enjoy the movies and novels they like in one application.

4) E-commerce companies need to evaluate and maximize the online promotion programs that have been run in order to attract more customers' interest in using the application. This can be optimized through a loyalty program that can be exchanged for e-vouchers which can be used at any store that collaborates with e-commerce applications without terms and conditions, so that customers will feel satisfied and will have an impact on continuous application use. 
5) E-commerce companies need to optimize the role of customer value perception through the positive values that are instilled in them. This can be done through CSR programs at every opportunity, in the form of social assistance programs, the creation of green open parks, as well as disaster relief programs such as floods, fires, and the ongoing Covid-19 pandemic.

\section{REFERENCES}

Davis, F. D. (1989). Perceived Usefulness, Perceived Ease of Use, and User Acceptance of Information Technology. Mis Quarterly, 13(3), 319-340. https://doi.org/10.5962/bhl.title.33621

Ding, C. G., \& Tseng, T. H. (2015). On the relationships among brand experience, hedonic emotions, and brand equity. European Journal of Marketing, 49(7-8), 994-1015. https://doi.org/10.1108/EJM-04-2013-0200

Ghozali, I. (2017). Structural Equation Modeling Konsep dan Aplikasi dengan Program Amos 24. Badan Penerbit UNDIP. Semarang.

Havidz, H. B. H., \& Mahaputra, M. R. (2020). Brand Image and Purchasing Decision: Analysis Of Price Perception And Promotion (Literature Review Of Marketing Management). Dinasti International Journal of Economics, Finance \& Accounting, 1(4), 727-741.

Išoraite, M., \& Miniotienè, N. (2018). Electronic Commerce: Theory and Practice. IJBE (Integrated Journal of Business and Economics), 2(2), 73. https://doi.org/10.33019/ijbe.v2i2.78

Kotler, P., \& Keller, K. L. (2018). Marketing Management. In Prentice Hall (14th ed.). Pearson Education, Inc. https://doi.org/10.4324/9781315099200-17

Kotler, P., Wong, V., Saunders, J., \& Armstrong, G. (2005). Principles of Marketing. (4th ed.). Person Edication, Inc. https://doi.org/10.2307/2224326

Kwilinski, A., Volynets, R., Berdnik, I., Holovko, M., \& Berzin, P. (2019). E Commerce: Concept and legal regulation in modern economic conditions. Journal of Legal, Ethical and Regulatory Issues, 22(Special Issue 2), 1-6.

News from Indonesia.go.id. (2021, February $23^{\text {rd }}$ ). Bisnis E-Commerce Semakin Gurih. Indonesia.go.id. https://www.indonesia.go.id/kategori/indonesia-dalam-angka/2534/bisnis-ecommerce-semakin-gurih

News from Jet Commerce. (2021, March ${ }^{\text {st }}$ ). Transaksi e-commerce Meningkat Hingga Kuartal IV 2020, Tren e-commerce 2021 Diprediksi Tumbuh Positif. Jercomerrce. https://jetcommerce.co.id/update/transaksi-e-commerce-meningkat-hingga-kuartal-iv-2020-trene-commerce-2021-diprediksi-tumbuh-positif/

News from Katadata. (2021, April 21 ${ }^{\text {st }}$ ). Penggunaan E-Commerce Indonesia Tertinggi di Dunia. Katadata. https://databoks.katadata.co.id/datapublish/2021/06/04/penggunaan-ecommerce-indonesia-tertinggi-di-dunia

News from Sirco. (2020, August $\left.19^{\text {th }}\right)$. Menilik Tren Perkembangan E-Commerce Indonesia di 2020.Sirco. https://www.sirclo.com/menilik-tren-perkembangan-e-commerce-indonesia-di2020/

Nurhayati, N., \& Murti, W. W. (2012). Analisis Faktor yang mempengaruhi Minat Beli Ulang Masyarakat terhadap Produk Handphone. Jurnal UNIMUS, 8(9), 47-62.

Pham, H., \& Nguyen, T. (2019). The effect of website quality on repurchase intention with the mediation of perceived value: The case study of online travel agencies in Vietnam. Journal of Global Business Insights, 4(1), 78-91. https://doi.org/10.5038/2640-6489.4.1.1041

Putri, L. H. (2016). Faktor-faktor Yang Mempengaruhi Minat Pembelian Ulang Konsumen Terhadap Produk Naget Delicy. Jurnal Manajemen Dan Start-Up Bisnis, 1(2), 162-170.

Rita, P., Oliveira, T., \& Farisa, A. (2019). The impact of e-service quality and customer satisfaction on customer behavior in online shopping. Heliyon, 5(10), e02690. 
https://doi.org/10.1016/j.heliyon.2019.e02690

Saidani, B., Raras, L. A., \& Aditya, S. (2018). Analisis Pengaruh Brand Awareness, Product Quality Dan Ease of Use Terhadap Customer Perceived Value Pada E-Money Mandiri E-Toll Card. JRMSI - Jurnal Riset Manajemen Sains Indonesia, 9(2), 320-336. https://doi.org/10.21009/jrmsi.009.2.08

Shafiee, M. M., \& Bazargan, N. A. (2018). Behavioral customer loyalty in online shopping: The role of e-service quality and e-recovery. Journal of Theoretical and Applied Electronic Commerce Research, 13(1), 26-38. https://doi.org/10.4067/S0718-18762018000100103

Surjaatmadja, S., \& Purnawan, D. (2018). International Review of Management and Marketing Store Image, Service Quality, and Familiarity on Purchase Intention of Private Label Brand in Indonesia. International Review of Management and Marketing, 8(1), 79-85.

Wilson, N., Alvita, M., \& Wibisono, J. (2021). the Effect of Perceived Ease of Use and Perceived Security Toward Satisfaction and Repurchase Intention. Jurnal Muara Ilmu Ekonomi Dan Bisnis, 5(1), 145. https://doi.org/10.24912/jmieb.v5i1.10489 